\title{
Tek"hik Sipil
}

DAFTAR ISI

Pengaruh Penggunaan Fly Ash Pada Beton Mutu Normal Dan Mutu Tinggi Ditinjau Dari Kuat Tekan Dan Absorbsi

Borris Berqa Leovie Haf

Perencanaan Perlindungan Dan Perbaikan Pantai Desa Banyusangka Kecamatan Tanjungbumi Kabupaten Bangkalan Madura

Hari Eko Meiyanto

Kajian Biaya Operasional Kendaraan Angkutan Penumpang Umum Kota Malang Khoirul Abadi

Pengaruh Penambahan Serbuk Bata Merah Terhadap Stabilitas Tanah Lempung Sebagai Tanah Dasar Jalan

Moch. Sholeh ${ }^{1}$,Dandung Novianto ${ }^{2}$,Gerard Aponno

$.20-26$

Penetapan Model Bangkitan Pergerakan Untuk Beberapa Tipe Perumahan Di Kota Pematangsiantar Muhammad Efrizal Lubis ${ }^{1}$,Novdin M Sianturi ${ }^{2}$............................................................2 $27-34$

Studi Kebutuhan Bukaan Pada Bangunan Perumahan Type Menengah Dengan Pendekatan Pencahayaan Ode Rapija GW

Batako Lumpur Lapindo Sebagai Alternatif Material Pasangan Dinding Rofikatul Karimah

Studi Perencanaan Normalisasi Sungai Kali Sono Di Kota Madiun

Sribanun Laila Sa'adah Heremba

$49-53$

(๑)Algoritma Genetik Untuk Meningkatkan Kinerja Model Tangki Standar Pada Analisa Transformasi Data Hujan Menjadi Data Aliran Sungai

Sulianto

Pengaruh Material Dinding Semen Eceng Gondok Terhadap Penyerapan Suara (Fungsi Akustik)

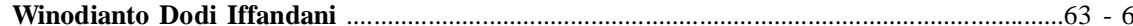

Perbandingan Mortar Berpasir Pantai Dan Sungai 